\title{
Nanoakışkan Kullanımında Ani Daralma ve Ani Genişleme Bağlantı Elemanlarının Akış Karakteristiklerinin Sayısal Olarak İncelenmesi
}

\author{
Nehir Tokgöz ${ }^{1 *}$, Mürüvvet Avc1 ${ }^{1}$, Mehmet Tahir Erdinç ${ }^{2}$, Önder Kaşka ${ }^{3}$ \\ ${ }^{* 1}$ Osmaniye Korkut Ata Üniversitesi, Mühendislik Fakültesi, Enerji Sistemleri Mühendisliği Bölümü, Osmaniye, Türkiye, (ORCID: 0000-0001-9264-9971), \\ nehirtokgoz@osmaniye.edu.tr \\ ${ }^{1}$ Osmaniye Korkut Ata Üniversitesi, Mühendislik Fakültesi, Enerji Sistemleri Mühendisliği Bölümü, Osmaniye, Türkiye, (ORCID: 0000-0001-8156-143X), \\ muruvvet.oku@gmail.com \\ ${ }^{2}$ Tarsus Üniversitesi, Mühendislik Fakültesi, Makine Mühendisliği Bölümü, Tarsus, Türkiye, (ORCID: 0000-0003-2201-2937), \\ mtahirerdinc@tarsus.edu.tr \\ ${ }^{3}$ Osmaniye Korkut Ata Üniversitesi, Mühendislik Fakültesi, Makine Mühendisliği Bölümü, Osmaniye, Türkiye, (ORCID: 0000-0002-7284-2093), \\ onderkaska@osmaniye.edu.tr
}

(İlk Geliş Tarihi 4 Ağustos 2021 ve Kabul Tarihi 13 Kasım 2021)

(DOI: $10.31590 /$ ejosat.978927)

ATIF/REFERENCE: Tokgoz, N., Avcı, M., Erdinç, M.T \& Kaska, O. (2021). Nanoakışkan Kullanımında Ani Daralma ve Ani Genişleme Bağlantı Elemanlarının Akış Karakteristiklerinin Sayısal Olarak İncelenmesi. Avrupa Bilim ve Teknoloji Dergisi, (27), 10731086.

Öz

Yapılan bu çalışmada endüstriyel sistemlerde en çok kullanılan iki farklı tesisat bağlantı elamanının (ani daralma ve ani genişleme) içerisinden nanoakışkan geçirilerek bu bağlantı parçalarının basınç düşüşleri ve kayıp katsayıları sayısal olarak incelenmiştir. Nanoakışkan, temel akışkan su alınarak içerisine farklı konsantrasyonlarda alüminyum, bakır ve titanyum esaslı nanoparçacıkların eklenmesiyle elde edilmiştir. Artan konsantrasyonun basınç kaybı ve akış yapısı üzerinde etkisini incelemek için farklı konsantrasyonlarda farklı nanoakışkanlar incelenmiştir. Nanoakışkanların termofiziksel özellikleri daha önce yapılmış olan çalışmalardan alınmıştır. Hesaplama sonuçları, literatürdeki sonuçlar ile doğrulanmıştır. Sayısal çözümlemelerde yaygın olarak tercih edilen Standart k- $\varepsilon$ ve Standart k- $\omega$ türbülans modeli olmak üzere 2 farklı türbülans modeli kullanılmıştır. Elde edilen hesaplar sonucunda incelenen her akışkanda, konsantrasyon arttıkça viskozitenin artışı ile yerel kayıpların da arttığı ortaya konulmuştur. En uygun türbülans modelinin bütün bağlantı parçaları için k- $\varepsilon$ olduğu belirlenmiştir.

Anahtar Kelimeler: Sayısal, Bağlantı elemanı, Nanoakışkan, Yerel kayıp, Basınç düşüşü

\section{Numerical Investigation of Flow Characteristics of Sudden Contraction and Sudden Expansion Fittings with Nanofluid Usage}

\begin{abstract}
In this study, the pressure drop and the pressure drop coefficient of nanofluid have been numerically investigated for two different types of fittings ( sudden contraction and sudden expansion) to be used commonly in the industrial systems. Nanofluid was obtained to mix the base water $\left(\mathrm{H}_{2} \mathrm{O}\right)$ fluid with different concentration of aluminum $(\mathrm{Al})$, copper $(\mathrm{Cu})$, and titanium (Ti) nanoparticles. Different nanofluids with different concentrations were investigated in order to examine the effect of increasing concentration on pressure loss and flow structure. The thermophysical properties of the nanofluids were taken from the previous studies. The results were validated by the previous literature. Two different turbulence models frequently used in the numerical analysis, Standard k- $\varepsilon$ and Standard k- $\omega$, were chosen in this study. As a result of this numerical study, it was observed that increasing concentration ratio causes higher pressure drop due to increment of the viscosity. It was also obtained that the most suitable turbulence model is k- $\varepsilon$ for both connection fittings.
\end{abstract}

Keywords: Numerical, Fittings, Nanofluid, Local loss, Pressure drop

* Sorumlu Yazar: nehirtokgoz@osmaniye.edu.tr 


\section{Giriş}

Günümüzde endüstrinin her alanında 1sı transferine yönelik yapılan araştırmaların temel amacı; enerjinin etkin ve verimli şekilde kullanılmasına yöneliktir. Enerji tüketen cihazların verimliliğini artırarak, mevcut enerjinin en iyi şekilde kullanılması araştırmacıların birinci hedefi haline gelmiştir. Bu kapsamda yapılan çalışmalar neticesinde 1sıyı transfer etmek için tasarlanan 1Sı değiştiricilerinin verimlilik açısından daha etkili, maliyet açısından daha uygun olması amaçlanmıştır. Enerjiyi etkin şekilde kullanıp 1sı transferini artırmaya yönelik çalışmalar aktif, pasif ve karma yöntemler olarak bilinmektedir. Pasif yöntemler, genişletilmiş yüzeyler, kanatçıklar gibi dış güç kullanılmasını gerektirmeyen yöntemlerken, aktif yöntemler de bir dış güç kaynağına ihtiyaç duyulur. Karma yöntemlerde ise aktif ve pasif yöntemlerden ikisi ya da daha fazlası birlikte kullanılır (Bergles, 1983). Isı transfer etkinliğini arttırmak için, iş yapan akışkanın (temel akışkan) içerisine mikro veya nano boyuttaki katı parçacıklar eklenerek yeni akışkan elde edilmesi günümüzde çok tercih edilen pasif yöntemlerden biridir. Burada amaç 1sı transferini artırmaya yönelik olsa da özellikle boru sistemlerindeki akışkanlarda çökelme, tortulaşma gibi birçok dezavantaj1 da beraberinde getirmiştir. Bu gibi durumlar da performansı düşürüp 1Sı değiştiricilerinin boyutunu ve maliyetini arttırmıştır (Şahin, 2006). Malzeme bilimi ve endüstrinin gelişmesiyle su, etilen, motor yağı gibi yaygın olarak kullanılan temel akışkanların içerisine ilave edilen partiküller mikro boyuttayken $(1 \mu \mathrm{m}=10-6 \mathrm{~m})$ yerini nano boyutlara $(1 \mathrm{~nm}=10-9$ m) bırakmıştır. Temel akışkan içerisine; boyutu $100 \mathrm{~nm}$ 'den daha düşük, 1sıl iletkenliği yüksek metalik ve metalik olmayan parçacıklar ilave edilerek nanoakışkan adı verilen yeni akışkanlar elde edilmiştir. Nanoakışkan kavramı ilk kez Choi ve arkadaşları tarafindan ortaya konulmuştur. Nanoakışkanların tercih edilme nedenlerinin başında isı iletim katsayılarını geleneksel akışkanlara göre çok yüksek olması ve basınç düşümünü çok fazla arttırmamalarıdır. Böylece yüksek 1sı transfer performansı ile daha küçük boyutlarda ısı değiştiricisi yapma imkânı sunmaktadır (Choi \& Eastman, 1995). Nano parçacıkların aynı hacimsel konsantrasyonda mikro parçacıklara kıyasla daha fazla yüzey alanına sahiptir. Mikro boyuttaki partiküllerle hazırlanan süspansiyonların kanallarda tıkanmalara sebep olurken (Murshed, Leong, \& Yang, 2008) nanoparçacıkların boru içerisinde çökelme ve tortulaşma meydan getirmediği ve akış boyunca kanalı aşındırmadığı görülmüştür. Ayrıca nanoakışkan kullanımı mikro kanal yüzey ile akışkan arasındaki sıcaklık farkını azaltıp, ısıl direncin azalmasına yol açmıştır. Bütün bunların sonucunda araştırmacılar nano boyutlu katı parçacıkların kullanılmasıyla ısı transferinin büyük ölçüde iyileştirilebileceğini görmüşlerdir. Bu olumlu sonuçlar neticesinde de güneş kolektörleri, 1sı boruları, nükleer reaktörler, elektronik soğutma sistemleri, otomobil radyatörleri vb. uygulamalar için muhtemel çalışma sıvıları olarak kabul edilebileceğini düşünmüşlerdir (Ganvir, Walke, \& Kriplani, 2017; Hassanzadeh \& Tokgoz, 2017; Tokgöz, Alıç, Kaşka, \& Aksot, 2018).

Awang, su ve etilen glikol gibi temel akışkanlar ile nanopartikül boyutundaki materyali karıştırıp 1sı transferini inceleyerek, nanoakışkanları regresyon denkleminin geliştirilmesine odaklanmıştır. Çalışmaları sonucunda, nanoakışkanların viskozite, özgül 1sı yoğunluk ve yoğunluk oranı ile ilgili ortalama sapma değerleri bulmuştur (Awang, 2010). Hosseini vd. termal iletkenlik, viskozite, yoğunluk ve özgül 1sı e-ISSN: 2148-2683 gibi nano sıvıların fiziksel özellikleri hakkında mevcut tüm formül ve korelasyonları gözden geçirip sınıflamışlardır. Yaptıkları incelemeler ile nano sıvıların fiziksel özellikleri üzerine parçacık konsantrasyonu, parçacık ve baz sıvısının fiziksel özellikleri, sıcaklık gibi birçok faktörün etki ettiğini görmüşlerdir. Tüm korelasyonun parçacık boyutu ve malzemesine bağlı olduğunu yüksek partikül hacmi konsantrasyonunda viskozite, yoğunluk ve özgül 1sının etkinliğinin daha belirgin olduğunu fark etmişlerdir ve burada viskozite, yoğunluk ve özgül ısının sabit olduğunu varsaymışlardır (Hosseini, Shahrjerdi, \& Vazifeshenas, 2011). Mahagaonkar vd. çalışmalarını kütlece $\% 60$ etilen glikol ve \%40 su bazlı akışkan içinde alüminyum oksit $\left(\mathrm{Al}_{2} \mathrm{O}_{3}\right)$ antimon-kalay oksit $\left(\mathrm{Sb}_{2} \mathrm{O}_{5}, \mathrm{Sn}_{2} \mathrm{O}_{2}\right)$ ve çinko oksit $(\mathrm{ZnO})$ nanopartikülleri içeren üç farklı nanoakışkan üzerinde gerçekleştirmişlerdir. İlk olarak temel akışkanın yoğunluğu için bir test sunmuşlar, sonra bu nanoakışkanların farklı hacmi konsantrasyonu için $0{ }^{\circ} \mathrm{C}$ ila $50^{\circ} \mathrm{C}$ sıcaklık aralığında yoğunluk ölçümlerini incelemişlerdir. Mahagaonkar ve arkadaşları, yaptıkları çalışmalar sonucunu yaygın olarak kullanılan teorik denklemler ile karşılaştırmış ve ölçümler arasındaki en iyi uyumun $\mathrm{Al}_{2} \mathrm{O}_{3}$ ve $\mathrm{Sb}_{2} \mathrm{O}_{5}, \mathrm{Sn}_{2} \mathrm{O}_{2}$ içeren nanoyakıtlar için elde etmişlerdir. Bununla birlikte genel teorik deneyler arasındaki sapmanın $\mathrm{ZnO}$ nanoakışkanı ile daha yüksek olduğu ve partikül hacmi konsantrasyonuyla arttığını gözlemlemişlerdir (Vajjha, Das, \& Mahagaonkar, 2009). Timofeeva ve diğerleri, nanoakışkanlarda viskozite, 1 sıl iletkenlik ve soğutma verimliliği gibi kavramların etkisini incelemişlerdir. Tek fazlı sıvılar için soğutma verimliliği ölçümlerini analiz edip, 1s1 transferi için önemli olan nanoakışkanların özelliklerini belirlemişlerdir. Timofeeva ve arkadaşları, nano boyuttaki parçacıkların temel akışkan içindeki konstantrasyonun 1sı transferini artırmak için en etkili parametre olduğunu ortaya koymuşlardır(Timofeeva, Yu, France, Singh, \& Routbort, 2011). Duangthongsuk vd. $\mathrm{Al}_{2} \mathrm{O}_{3}-\mathrm{su}$ içeren nanoakışkanların kaynama özelliklerine ilişkin bir deney yürütmüşlerdir. Araştırmalarının temel amacı, nanoakışkan konsantrasyonunun ve basıncının, su ile karşılaştırarak 1sı iletim katsayısı ve 1sı akısı üzerindeki etkisini incelemektir. Deneysel aparatı su ile kalibre etmişler ve deneysel sonuçları Rohsenow denklemi ile ortaya koymuşlardır. Duangthongsuk ve arkadaşları yaptıkları deney sonucunda, $\mathrm{Al}_{2} \mathrm{O}_{3}$-su içeren nanoakışkanların $1 \mathrm{~S} 1$ transfer katsayısının suyunkinden düşük olduğunu ve konsantrasyon yüksek olduğunda azalma eğiliminde olduğunu görmüşlerdir (Duangthongsuk, Yiamsawasd, Selim Dalkilic, \& Wongwises, 2013). Kulkarni, vd. süspansiyon halinde metalik nanopartiküller içeren nano sıvıların, temel sıvının termal iletkenliğini önemli miktarda arttırdığı fikrine dair çalışmalar yapmışlardır. Bunun için ilk olarak $\mathrm{SiO}_{2}, \mathrm{Al}_{2} \mathrm{O}_{3}$ ve $\mathrm{CuO}$ içeren nano sıvılarının çeşitli sıcaklıktaki farklı hacim yüzdelerindeki özelliklerini incelemişler, viskozite üzerine sıcaklık ve çap etkisini araştırmışlardır. Kulkarni ve arkadaşları, nanoakışların viskozitesinin nano partikül konsantrasyonunun bir fonksiyon olduğu ve konsantrasyonla arttığı sonucuna ulaşmışlardır. Parçacık boyutu arttıkça viskozitenin azaldığını görmüşlerdir. Ayrıca yaptıkları çalışmalar sonucunda, parçacık boyutunun, 1S1 transfer katsayısını etkilediğini ve çap ne kadar büyük olursa, 1S1 transfer katsayısının o kadar yüksek olduğunu görmüşlerdir. Yoğunluğa bağlı olarak viskozitenin arttığını görmüşler ve konsantrasyon arttıkça basınç kaybının da arttığı sonucuna ulaşmışlardır (Kulkarni, Namburu, \& Das, 2016). Bianco vd. çalışmalarında, sabit ve homojen bir 1sı akısına tabi tutulan bir dairesel tüp içindeki su- $\mathrm{Al}_{2} \mathrm{O}_{3}$ içeren nanoakıșkanı sayısal olarak incelemişlerdir. $100 \mathrm{~nm}$ boyuttaki parçacıklar için tek veya iki fazlı model kullanmışlardır. Bianco ve arkadaşları yaptıkları 
çalışmalar sonucunda tek ve çift faz model sonuçları arasındaki ortalama 1sı transfer katsayısındaki maksimum fark yaklaşık \% 11 olduğu ve nanoakışlar için taşınım 1sı transfer katsayısı temel akışkanınkinden daha büyük olduğu sonucuna ulaşmışlardır. Ayrıca 1S1 transferinin arttırılması partikül hacmi konsantrasyonuyla birlikte arttığını, ancak bunun kayma gerilmesini de arttırdığını görmüşlerdir. Yaptıkları çalışmalar ile Reynolds sayısı arttıkça 1Sı transferi daima geliştiğini de fark etmişlerdir (Bianco, Chiacchio, Manca, \& Nardini, 2009). Artuç, akışkanların 1sıl iletkenliklerini artırmak için küçük metal parçacıklar kullanılarak nanoakışkanlar elde edilebileceğini düşünmektedir. Karışımın içerisindeki farklı boyutlarda bakır ve gümüş metalin ısıl iletkenliği akışkanınkinden fazla olduğu için karışımın ısıl iletkenliğinin de artacağını söylemiştir. Artuç, elde ettiği sonuca göre 1sıl iletkenliğin nanoakışkanların hacimsel değerinin artışıyla arttığını belirlemiştir. Belirli bir artış değerinden sonra ise doyuma ulaştı̆̆ını görmüştür. Nanoakışkanlarda 1S1 iletimini etkileyen faktörlerin boyut, hacimsel oran, sıcaklık, 1sı iletim katsayısı gibi faktörler olduğu sonucuna varmıştır (Artuç, 2007). Gavtash ve arkadaşları bu çalışmalarında Fluent CFD yazılımını kullanarak, nano sıvıların silindirik 1sı boruların termal performansı üzerindeki etkilerini modelleme ve simule etmeyi amaçlamışlardır. Sıvı akışkan (su) içerisinde nano parçacık varlı̆̆ında basınç ve eksenel hızı araştırmışlardır. Parçacık yoğunluğunun ve boyutunun etkisini incelemişler ve sistemin çalışma sıvısı olarak nanoakışkan kullanıldığında 1S1 borusunun 1s1 performansının iyileştiğini görmüşlerdir. Ayrıca ısının 1 sıl direncinin parçacık konsantrasyonun seviyesi arttıkça ve partikülün yarıçap1 azaldıkça düştüğü sonucuna varmışlardır (Gavtash, Hussain, Layeghi, \& Lafmejani, 2012). Kakaç ve Pramuanjaroenkijj, çalışma sıvısı olarak kullandıkları termal sistemlerde konvektif ısı aktarım hızını artırmak amacıyla nanoakışkan kullanımının avantajını incelemişlerdir. Tek ve iki fazlı sistemlerde çalışmalar yapmışlardır. Nano yakıtlar tarafindan 1S1 transferinin arttırılmasının, partiküller arasındaki fiziksel etkileşim modelinde bulunan diferansiyel denklemlere bağlı olduğunu düşünmüşlerdir. Karışım modelinin, fiziksel özelliklerinin birleştirilmesi ve daha az hesaplama gücü gereksinimi gibi avantajlara rağmen, bazı çalışmalarda tek fazlı ve iki fazlı modellerin sonuçlarının çok benzer olduğunu temel farkın, fazların birbirine göre sürüklenme hızlarının etkisinden oluştuğunu görmüşlerdir. Ve iki fazlı modelin daha karmaşık ve hesaplama açısından daha maliyetli olduğunu her bir faz için denklemlerin ayrı ayrı çözülmesi ve fazlar arası koşullardan kaynaklandığını belirtmişlerdir (Kakaç \& Pramuanjaroenkij, 2016)

Bu çalışmada tesisat bağlantı parçası olarak en çok kullanılan ani daralma ve ani genişleme bağlantı parçalarının içerisinden nanoakışkan geçirilmesiyle oluşan basınç farkı ve yerel kayıp katsayısı sayısal olarak incelenmiş, basınç ve hız dağılımları çıkarılmıştır. Tesisat projelerinde amaç seçilen pompanın sürtünme ve yerel kayıpları karşılayarak istenilen noktaya istenilen basınçta akışkanı taşımasıdır. Bundan dolayı boru çapı hesabı yapılırken sürtünme kayıpları kadar yerel kayıpların da mutlaka göz önünde bulundurulması gerekmektedir.

Nanoakışkanlar üzerine yapılan çalışmalar incelendiğinde daha çok 1S1 transferi üzerine etkisi incelenmiş oluşturduğu kayıplar ihmal edilmiştir. Konsantrasyonlarının değiştirilmesiyle termofiziksel özellikleri değişen nanoakışkanların meydana getirdiği kayıplar hesaplanmıştır. Yerel kayıpları oluşturan bağlantı malzemelerinin içinden farklı hacim konsantrasyonlarında alüminyum, titanyum ve bakır esaslı nano parçacıklar ilavesiyle elde edilen nanoakışkanlar geçirilmiştir. Hesaplanan basınç kayıpları suyla mukayese edilerek bağıl yerel kayıp katsayıları sunulan çalışma sonucunda elde edilmiştir. $\mathrm{A}_{2} \mathrm{O}_{3}$ için beş farklı, $\mathrm{Ti}_{2} \mathrm{O}$ için dört farklı, $\mathrm{CuO}$ için ise üç farklı hacim konsantrasyonu belirlenmiş belirlenen konsantrasyondaki nanoakışkanların termofiziksel özellikleri literatürde yer alan çalışmalardan alınmıştır. Ayrıca yapılan çalışma literatürde yaygın olarak kullanılan sonuçlarla (Çengel, Cimbala, \& Engin, 2008) mukayese edilerek doğrulanmıştır. Türbülans modellerinin akış alanı üzerine etkisinin de incelendiği bu çalışmada yaygın kullanılan iki farklı turbulans modeli olan standart k- $\epsilon$, ve standart k- $\omega$ türbülans modeli kullanılmıştır.

\section{Materyal ve Metot}

\subsection{Modelin Tanımlanması}

İncelenen ani daralma ve ani genişleme bağlantı parçaları ANSYS-Fluent paket programında üç boyutlu modellenip çözülmüştür. Yapılan çalışmada akışın tam gelişmiş olması için, hidrodinamik giriş uzunluğu $\mathrm{L}_{\mathrm{h}}=10 \mathrm{~d}$ olarak alınmıştır. Reynolds sayısı 5000 olarak belirlenmiştir. Reynolds sayısı eşitlik 1'de gösterildiği şekilde tanımlanmıştır;

$R e=\frac{\rho V d}{\mu}$

Burada $\rho, V$, d ve $\mu$ sırasıyla akışkanın yoğunluğu $\left(\mathrm{kg} / \mathrm{m}^{3}\right)$, ortalama akış hızı (m/s), çap (m) ve $\mu$ dinamik viskozitedir (kg $/ \mathrm{ms})$.

Tablo 1. Kullanılan Bağlantı Parçalarının boyutları

\begin{tabular}{|c|c|c|c|}
\hline Boru & $\begin{array}{c}\text { Giriş Çap1 } \\
(\mathrm{m})\end{array}$ & $\begin{array}{c}\text { Çıkış Çap } 1 \\
(\mathrm{~m})\end{array}$ & $\begin{array}{c}\text { Uzunluğu } \\
(\mathrm{m})\end{array}$ \\
\cline { 4 - 4 } & $2 \mathrm{~d}$ & $\mathrm{~d}$ & $\mathrm{x}$ \\
\hline Ani Daralma & $\mathrm{d}$ & $2 \mathrm{~d}$ & $50 \mathrm{~d}$ \\
\hline $\begin{array}{c}\text { Ani } \\
\text { Genişleme }\end{array}$ & & & \\
\hline
\end{tabular}

Kullanılan bağlantı malzemelerinin 3 boyutlu şematik gösterimi ve uygulanan sınır şartları aşağıdaki tabloda özetlenmiştir. 


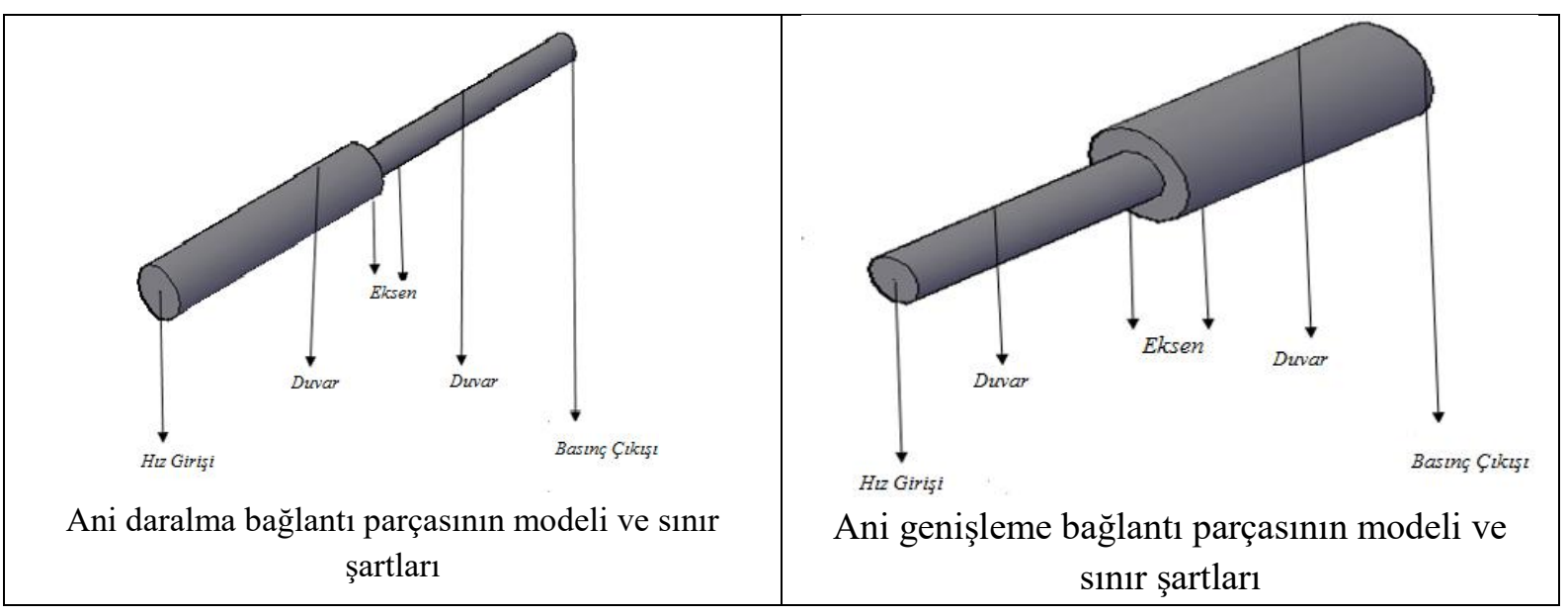

Şekil 1. Bağlantı malzemelerinin 3 boyutlu şematik gösterimi ve uygulanan sınır şartları

\subsection{Modellerin Sinır Şartları}

Ani daralma ve ani genişleme bağlantı parçası için modellenen geometride, akışkanın giriş kısmı uniform hız sınır şartı, çıkış kısmı için ise basınç çıkışı şartı tanımlanmıştır.

\subsection{Saytsal Metot ve Denge Denklemleri}

Yapılan sayısal analizlerde, Reynolds Ortalamalı NavierStokes (RANS) denklemleri kullanılmıştır. İkinci dereceden upwind ayrıklaştırma algoritmaları kullanılmıştır. Yakınsama kriteri $10^{-6}$ alınmıştır.

Süreklilik denklemi:

$$
\frac{\partial u}{\partial x}+\frac{\partial v}{\partial y}+\frac{\partial w}{\partial z}=0
$$

Momentum denklemi:

$$
\frac{\partial\left(\rho u_{i} u_{j}\right)}{\partial x_{j}}=-\frac{\partial p}{\partial x_{i}}+\frac{\partial}{\partial x_{j}}\left[\mu\left(\frac{\partial u_{i}}{\partial x_{j}}+\frac{\partial u_{j}}{\partial x_{i}}\right)-\rho \overline{u_{\imath}^{\prime} u_{j}^{\prime}}\right]
$$

\subsubsection{Türbülans Modelleri}

Endüstriyel tesislerde, mühendislik hesaplarında problem analizleri için seçilen türbülans modeli çok önemlidir. Seçilen türbülans modelinde akışkanın fiziksel özellikleri, akışta girdap olup olmaması oldukça etkilidir. Akışkandaki çalkantılar doğru türbülans modeli seçimi ile analiz edilebilir. $\mathrm{Bu}$ çalışmada modeller arasındaki farklıkları ortaya koyabilmek için $\mathrm{k}-\varepsilon$ ve $\mathrm{k}-$ $\omega$ türbülans modelleri kullanılmıştır. $\mathrm{Bu}$ modelde türbülans kinetik enerji, $\mathrm{k}$ ve türbülans dağılım hızı, $\varepsilon$ aşağıda verilen denklemler çözülür.

$$
\begin{gathered}
\frac{\partial\left(u_{j} k\right)}{\partial t}=\mu_{t} \frac{\partial u_{i}}{\partial x_{j}}\left(\frac{\partial u_{i}}{\partial x_{j}}+\frac{\partial u_{j}}{\partial x_{i}}\right)+\frac{\partial}{\partial x_{j}}\left(\frac{\mu_{t}}{\sigma_{k}} \frac{\partial_{k}}{\partial x_{j}}\right)-\rho \epsilon \\
\frac{\partial\left(u_{j} \epsilon\right)}{\partial t}=C_{\epsilon 1} \frac{\epsilon}{k} \mu_{t} \frac{\partial u_{i}}{\partial x_{j}}\left(\frac{\partial u_{i}}{\partial x_{j}}+\frac{\partial u_{j}}{\partial x_{i}}\right)+\frac{\partial}{\partial x_{j}}\left(\frac{\mu_{t}}{\sigma_{k}} \frac{\partial_{\epsilon}}{\partial x_{j}}\right) \\
-\rho C_{\epsilon 2} \frac{\epsilon^{2}}{k}
\end{gathered}
$$

Burada $k, \epsilon, \sigma_{k}$ sırasıyla; türbülans kinetik enerjisi, enerjinin yayılımı ve türbülanslı Prandtl sayısıdır.

Türbülans Eddy viskozitesi ise:

$$
\mu_{t}=C_{\mu} \frac{k^{2}}{\epsilon}
$$

Burada $C_{\mu}, C_{\epsilon 1}, C_{\epsilon 2}$ model katsayılarıdır ve şu şekilde ifade edilir:

$$
\begin{aligned}
& C_{\mu}=\left(\frac{u_{*}^{2}}{k}\right)^{2} \\
& C_{\epsilon 1}=C_{\epsilon 2}-\frac{\kappa}{\sqrt{C_{\mu} \sigma_{\epsilon}}}
\end{aligned}
$$

$u_{*}$ : Sürtünme hızı, Çözümlemede kullanılan model sabitleri ise:

$C_{\epsilon 1}=1.44, C_{\epsilon 2}=1.92, C_{\mu}=0.09, \sigma_{k}=1.0, \quad \sigma_{\epsilon}=1.3$

Çözümlemede kullanılan diğer türbülans modeli ise standard $\mathrm{k}$ - $\omega$ türbülans modelidir. Bu model daha çok, sınır tabaka akışlarında, serbest kayma tabakalı akışlarda daha üstün sonuçlar vermektedir. Özellikle büyük akış ayrılmalarının olduğu sınır tabaka akışlarında kullanılmaktadır. Burada yine türbülans kinetik enerjisi k, enerjinin yayılımı ifadesi ise $\omega$ ile gösterilmektedir (Wilcox, 1988)

$$
\begin{aligned}
\frac{\partial k}{\partial t}+u_{j} \frac{\partial k}{\partial x_{j}}=\tau_{i j} & \frac{\partial u_{i}}{\partial x_{j}}-\beta^{*} k \omega \\
& +\frac{\partial}{\partial x_{j}}\left[\left(v+\sigma^{*} v_{T}\right) \frac{\partial k}{\partial x_{j}}\right]
\end{aligned}
$$

Burada kinematik Eddy viskozitesi şu şekilde ifade edilir:

$$
v_{T}=\frac{k}{\omega}
$$

$\alpha, \beta, \beta^{*}, \sigma$ ve $\sigma^{*}$ model katsayılarıdır ve sirayla $5 / 9,3 / 40,9 / 100$, $1 / 2$ ve $1 / 2$ değerlerine eşittir. 


\subsection{Yerel Kayıplar ve Kayı Katsayısı}

Akış problemlerinde göz önünde bulundurulması gereken en önemli etken, borudaki akışın rejimi, borunun fiziksel boyutları, boru yapımında kullanılan malzeme, akışkanın yön değiştirmesini sağlayan veya boruları birleştirmek için kullanılan bağlantı malzemelerinde meydana gelen enerji kayıplarıdır. Akışkan bir yerden başka bir yere taşımak için kullanıla pompalar oluşan bu enerji kayıplarını karşılayacak şekilde seçilirler. $\mathrm{Bu}$ sebeple meydana gelen kayıplar ne kadar küçük olursa seçilen pompa da o kadar küçük boyutlarda olacak böylece enerji tasarrufu sağlanmış olacaktır. Bir boru akışında sürtünmeden kaynaklanan kayıplar sürekli yük kayıpları diye adlandırılırken bağlantı malzemelerinin neden olduğu kayıplar yerel kayıplar olarak adlandırılmaktadır. Bu bağlantı elemanlarına örnek olarak; sürekli daralıp, genişleyen borularda geçişi kolaylaştıran difüzörler, giriş ve çıkış çaplarındaki ani genişleme ve ani daralmalar, T geçişi, akışı kontrol edip yönlendiren vanalar sayılabilir. Bu bağlantı elemanlarında yerel yük kayıpları (m) aşağıda verilen ifadeler ile hesaplanabilir;

$$
H_{k}=\frac{\Delta P}{\rho g}=K_{k} \frac{V^{2}}{2 g}
$$

$H_{k}$ : yerel yük kaybı (m), $\Delta P$ : iki nokta arasındaki basınç farkı $(\mathrm{Pa}), \rho$ : suyun yoğunluğu $\left(\mathrm{kg} / \mathrm{m}^{3}\right), g$ : yerçekimi ivmesi $(9,81$ $\left.\mathrm{m} / \mathrm{s}^{2}\right), K_{k}$ : yerel kayıp katsayısı, $V$ : ortalama akış hızıdır $(\mathrm{m} / \mathrm{s})$

$\mathrm{W}=\dot{w} \cdot \Delta P$

Burada $\mathrm{W}, \dot{w}, \Delta \mathrm{P}$ sırasıyla; akışkana aktarılan faydalı güç (Watt), hesaplanan hacimsel debi $\left(\mathrm{m}^{3} / \mathrm{s}\right)$ ve pompa giriş ve çıkışı arasındaki basınç farkıdır $(\mathrm{Pa})$.

\subsection{Nanoakışkanların Termofiziksel Özellikleri}

Temel akışkan su alınarak içerisine farklı konsantrasyonlarda $\mathrm{Al}_{2} \mathrm{O}_{3}, \mathrm{Ti}_{2} \mathrm{O}, \mathrm{CuO}$ esaslı nano parçacık ilave edilerek homojen nanoakışkanlar elde edildiği kabul edilmiştir. Beş farklı konsantrasyonda $\mathrm{Al}_{2} \mathrm{O}_{3}(\% 0,3, \% 0,5, \% 1, \% 2, \% 3)$, dört farkl konsantrasyonda $\mathrm{Ti}_{2} \mathrm{O}(\% 0.05, \% 0,1, \% 0,3, \% 0,5)$ ve üç farkl konsantrasyonda $\mathrm{CuO}(\% 1, \% 2, \% 4)$ kullanılmıştır. Her bir konsantrasyon için ayrı ayrı hesaplama yapılmıştır. Kullanılan nanoakışkanların termofiziksel özellikleri daha önce literatürde yapılan deneysel çalışmalardan alınarak aşağıdaki çizelgelerde özetlenmiştir.

Çizelge $1.20^{\circ} \mathrm{C}$ 'de Alüminyum Oksidin, $\mathrm{Al}_{2} \mathrm{O}_{3}$ Fiziksel Özellikleri (Özbey, 2016)

\begin{tabular}{|c|c|c|c|c|}
\hline Akışkanlar & $\begin{array}{c}\text { Yoğunluk, } \\
\underset{P}{\left(\mathrm{~kg} / \mathrm{m}^{3}\right)}\end{array}$ & 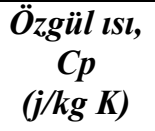 & $\begin{array}{c}\text { Dinamik Viskozite, } \\
\mu \\
(\mathrm{kg} / \mathrm{ms})\end{array}$ & $\begin{array}{c}\text { Isı İletim Katsayısı, } \\
\boldsymbol{k} \\
(W / m K)\end{array}$ \\
\hline$S u$ & 998.2 & 4182.0 & 0.001003 & 0.6 \\
\hline $\mathrm{Su}+\% 0.3 \mathrm{Al}_{2} \mathrm{O}_{3}$ & 1005.80 & 4145.20 & 0.0010862 & 0.608334 \\
\hline $\mathrm{Su}+\% 0.5 \mathrm{Al}_{2} \mathrm{O}_{3}$ & 1011.87 & 4110.86 & 0.00117021 & 0.619223 \\
\hline $\mathrm{Su}+\% 1.0 \mathrm{Al}_{2} \mathrm{O}_{3}$ & 1028.20 & 4036.67 & 0.00139827 & 0.644465 \\
\hline $\mathrm{Su}+\% 2.0 \mathrm{Al}_{2} \mathrm{O}_{3}$ & 1055.48 & 3925.80 & 0.0019319 & 0.685893 \\
\hline $\mathrm{Su}+\% 3.0 \mathrm{Al}_{2} \mathrm{O}_{3}$ & 1083.60 & 3810.77 & 0.0025689 & 0.728339 \\
\hline
\end{tabular}

Çizelge 2. $20^{\circ} \mathrm{C}$ 'de Titanyum Oksidin, $\mathrm{Ti}_{2} \mathrm{O}$ Fiziksel Özellikleri (Gedik vd., 2017)

\begin{tabular}{|c|c|c|c|c|}
\hline Akışkanlar & $\begin{array}{c}\text { Yoğunluk, } \\
P \\
(\mathrm{~kg} / \mathrm{m} 3)\end{array}$ & $\begin{array}{l}\ddot{O ̈ z g}_{\text {zül tsı, }} \\
\quad \text { Cp } \\
(\mathrm{j} / \mathrm{kg} \mathrm{K})\end{array}$ & $\begin{array}{c}\text { Dinamik Viskozite, } \\
\mu \\
(\mathrm{kg} / \mathrm{ms})\end{array}$ & $\begin{array}{c}\text { Isı İletim Katsayısı, } \\
\boldsymbol{k} \\
(W / m K)\end{array}$ \\
\hline $\mathrm{Su}+\% 0.05 \mathrm{Ti}_{2} \mathrm{O}$ & 1077.3 & 3858.3 & 0.000845 & 0.6569 \\
\hline $\mathrm{Su}+\% 0.1 \mathrm{Ti}_{2} \mathrm{O}$ & 1154.6 & 3573.7 & 0.000892 & 0.6953 \\
\hline $\mathrm{Su}+\% 0.3 \mathrm{Ti}_{2} \mathrm{O}$ & 1463.6 & 2736.8 & 0.001082 & 0.8656 \\
\hline $\mathrm{Su}+\% 0.5 \mathrm{Ti}_{2} \mathrm{O}$ & 1771.9 & 2192.8 & 0.001271 & 1.068 \\
\hline
\end{tabular}

Çizelge 3. $20^{\circ} \mathrm{C}$ 'de Bakır Oksidin, CuO Fiziksel Özellikleri (Bedir, 2013)

\begin{tabular}{|c|c|c|c|c|}
\hline Akışkanlar & $\begin{array}{c}\text { Yoğunluk, } \\
\mathbf{P} \\
(\mathrm{kg} / \mathrm{m} 3)\end{array}$ & $\begin{array}{c}\text { Özgül ısı, } \\
\text { Cp } \\
(\mathbf{j} / \mathbf{k g ~ K})\end{array}$ & $\begin{array}{c}\text { Dinamik } \\
\text { Viskozite, } \\
\mu \\
(\mathrm{kg} / \mathrm{ms})\end{array}$ & $\begin{array}{c}\text { Isı İletim } \\
\text { Katsayısı, } \\
\text { k } \\
(\mathbf{W} / \mathbf{m} \text { K) }\end{array}$ \\
\hline $\mathrm{Su}+\% 1 \mathrm{CuO}$ & 1051.418 & 4145.615 & 0.001387 & 0.645 \\
\hline $\mathrm{Su}+\% 2 \mathrm{CuO}$ & 1104.636 & 4109.150 & 0.001545 & 0.657 \\
\hline $\mathrm{Su}+\% 4 \mathrm{CuO}$ & 1211.072 & 4036.221 & 0.001762 & 0.694 \\
\hline
\end{tabular}




\section{BULGULAR VE TARTIŞMA}

Farkl 1 hacim konsantrasyonlarında ele alınan, $\mathrm{Al}_{2} \mathrm{O}_{3}, \mathrm{CuO}$ ve $\mathrm{TiO}_{2}$ nanoakışkanların sayısal analizleri sonucunda elde edilen veriler değerlendirilmiştir. Elde edilen verilerle hesaplanan yerel kayıp katsayıları literatürde kabul edilen (Çengel vd., 2008) yerel kayıp katsayıları ile mukayese edilmiştir. Ani daralma bağlantı parçası için $d^{2} / D^{2}$ oranına bağlı diyagram kullanılırken, ani genişleme bağlantı parçası için $\left(1-\frac{d^{2}}{D^{2}}\right)^{2}$ bağıntısı kullanılmıştır (Çengel et al., 2008). Analizler sonucunda elde edilen verilerde kullanılan türbülans modellerinin hangisinin referans alınan kaynağa yakın olduğu tespit edilip uygun modele karar verilmiştir. Kullanılan modellerle elde edilen sonuçların hepsi grafiklerle ve çizelgelerle sunulmuştur.

\subsection{Sonuçların Doğrulanması}

Yapılan bu çalışmada hesaplanan yerel kayıp katsayısı $\left(\mathrm{K}_{\mathrm{k}}\right)$ değerleri, (Çengel et al., 2008) tarafindan belirlenen kayıp katsayıları ile kıyaslanmıştır. Hesaplamada kullanılan iki farklı türbülans modelindeki değerler ve literatür sonuçları Tablo 2'de gösterilmiştir. Hesaplamalar sonucunda elde edilen sonuçlara göre k- $\varepsilon$ türbülans modeli kullanıldığında, sonuçlar literatürdeki sonuçlara daha yakın olduğu görülmektedir. Çözümlemelerde k$\omega$ Standart türbülans modeli kullanıldığı durumda literatürde yaygın kullanılan değere, en uzak değerin ise \% 23 farkla ani daralma bağlantı parçasında olduğu görülmektedir. k- $\omega$ Standart türbülans modeli kullanıldığı durumda yerel kayıp katsayısı değerinin fazla çıkması bu modelin çözümleme için uygun olmadığını göstermektedir.

Tablo 2 : Su İçin Elde Edilen Sonuçların Doğrulanması

\begin{tabular}{|c|c|c|c|}
\hline Bağlantı Parçası & $K_{k}(k-\varepsilon)$ & $K_{k}(k-\omega)$ & $\begin{array}{c}K_{k}(\text { Çengel vd., } \\
\text { 2008) }\end{array}$ \\
\hline Ani Daralma & 0.499 & 0.6305 & 0.48 \\
\hline Ani Genişleme & 0.602 & 0.639 & 0.58 \\
\hline
\end{tabular}

Değişen hacim konsantrasyonlarına göre $k-\varepsilon$ ve k- $\omega$ türbülans modelleri için hesaplanan yerel kayıp katsayıları Tablo 3 ve Tablo 4'te verilmiştir. Tablolar incelendiğinde, konsantrasyonun atmasıyla yerel kayıp katsayısının da arttığı görülmektedir. $\mathrm{Bu}$ durum akışkanın türbülanslı oluşu ve artan hacim konstrasyonun artmasıyla ile ilişkilendirilebilir.

Ani daralma ve genişleme bağlantı parçalarında köşelerde akış ayrılması oluşur ve akış bağlantı parçasının ortasında bulunan daralmış kesitte sıkışmaktadır. Bu da akışkanın enerji kaybetmesine neden olur.

Akışın hidrodinamik yapısını daha iyi açıklayabilmek için simetri eksenlerine tanımlanan yüzeylerdeki hız ve basınç dağılımları ani daralma ve ani genişleme için sırası ile Şekil 2, Şekil 3, Şekil 4 ve Şekil 5 'te sunulmuştur.
Tablo 3. Bağlantı Parçalarının Kayıp Katsayıları, $\mathrm{K}_{\mathrm{k}}$, k - $\varepsilon$ modeli $\left(\mathrm{Al}_{2} \mathrm{O}_{3}\right)$

\begin{tabular}{lcc}
\hline \multirow{2}{*}{ Akışkanlar } & \multicolumn{2}{c}{ Kayı̀ Katsayıları, $\mathbf{K}_{\mathbf{k}}$} \\
\cline { 2 - 3 } & Ani Daralma & Ani Genişleme \\
\hline $\mathrm{Su}$ & 0.4997 & 0.602 \\
$\mathrm{Su}+\% 0.3 \mathrm{Al}_{2} \mathrm{O}_{3}$ & 0.5034 & 0.607 \\
$\mathrm{Su}+\% 0.5 \mathrm{Al}_{2} \mathrm{O}_{3}$ & 0.5065 & 0.610 \\
$\mathrm{Su}+\% 1.0 \mathrm{Al}_{2} \mathrm{O}_{3}$ & 0.5146 & 0.620 \\
$\mathrm{Su}+\% 2.0 \mathrm{Al}_{2} \mathrm{O}_{3}$ & 0.5280 & 0.637 \\
$\mathrm{Su}+\% 3.0 \mathrm{Al}_{2} \mathrm{O}_{3}$ & 0.5424 & 0.654 \\
\hline
\end{tabular}

Tablo 4. Bağlantı Parçalarının Kayıp Katsayıları, Kk, k - $\omega$ Modeli $\left(\mathrm{Al}_{2} \mathrm{O}_{3}\right)$

\begin{tabular}{lcc}
\hline \multirow{2}{*}{ Akışkanlar } & \multicolumn{2}{c}{ Kayıp Katsayıları, $\mathbf{K}_{\mathbf{k}}$} \\
\cline { 2 - 3 } & Ani Daralma & Ani Genişleme \\
\hline $\mathrm{Su}$ & 0.6305 & 0.639 \\
$\mathrm{Su}+\% 0.3 \mathrm{Al}_{2} \mathrm{O}_{3}$ & 0.6463 & 0.644 \\
$\mathrm{Su}+\% 0.5 \mathrm{Al}_{2} \mathrm{O}_{3}$ & 0.6391 & 0.648 \\
$\mathrm{Su}+\% 1.0 \mathrm{Al}_{2} \mathrm{O}_{3}$ & 0.6487 & 0.658 \\
$\mathrm{Su}+\% 2.0 \mathrm{Al}_{2} \mathrm{O}_{3}$ & 0.6659 & 0.676 \\
$\mathrm{Su}+\% 3.0 \mathrm{Al}_{2} \mathrm{O}_{3}$ & 0.6844 & 0.694 \\
\hline
\end{tabular}

Şekil 2 incelendiğinde, ani daralma bağlantı parçası için konsantrasyon arttıkça basıncın da arttığı görülmektedir. Düşük konsantrasyonlarda $1 \mathrm{~Pa}$ mertebesinde olan basıncın yüksek konsantrasyonda $17 \mathrm{~Pa}$ değerine kadar çıkması bu durumun sonucu olarak açıklanabilir. Diğer bağlantı parçaları ile kıyaslandığında basınçta yaklaşık \%160 oranında bir artış olmuştur. Yani akışkana ilave daha fazla basınç enerjisi verilmesi gerektiği ortaya çıkmaktadır. Ani daralmadaki bu artışın nedeni ani girdap kopmalarından dolayı bağlantı parçalarının köşelerinde akış ayrılmalarının oluşmasından kaynaklanmaktadır. Ani daralma bağlantı parçası için $\mathrm{Al}_{2} \mathrm{O}_{3}$ nanoakışkanında konsantrasyon artışı ile hızın da artığı, özellikle ani girdap kopmalarının olduğu yerlerde hız dağılımının çok daha fazla sıklaştığı görülmüştür. Köşelerde türbülans girdaplarından dolayı hızda ani bir artış meydana gelmiştir. Bağlantı parçasının giriş kısmındaki büyük kesitte hız değeri $0,016 \mathrm{~m} / \mathrm{s}$ iken, çıkış kısmındaki küçük kesitte hız değeri aniden 10 katına çıkarak 0,16 $\mathrm{m} / \mathrm{s}$ değerine ulaşmıştır. Şekil 3'te görüldüğü gibi, her konsantrasyondaki ani genişleme bağlantı parçası için girişteki basıncın çıkışta düştüğü görülmektedir. Negatif basınçlar kesikli çizgiler ile sembolize edilmiştir. Ani genişlemeden hemen sonra keskin köşelere yakın yerlerde ölü akış alanları oluşmaktadır. Şekil 3 incelendiğinde ani genişleme bağlantı parçası için $\mathrm{Al}_{2} \mathrm{O}_{3}$ nanoakışkanında konsantrasyon artışı ile hızın da artığı görülmüştür. Maksimum hızın kesitin en dar olduğu yerde meydana gelmesi süreklilik denklemi gereği beklenen bir sonuçtur. Basınç dağılımının verildiği şekildeki gibi hız dağılımında da negatif hızlar kesikli çizgi ile gösterilmiştir. Akışkan keskin bir kenardan boruya girerken sahip olduğu hız yükünün büyük bir bölümünün kaybeder. Özellikle çok yüksek Reynolds sayılarında akışkanın keskin dönüşler yapması oldukça zordur. $\mathrm{Bu}$ dönüşleri yapabilmesi için enerji kaybetmesi 1078 
kaçınılmazdır. $\mathrm{Bu}$ dönüşler neticesinde şekilde de açıkça görüldüğü gibi köşelerde akış ayrılmları meydana gelerek yön değiştiren ikinci bir akış alanı oluşmuştur. Boru boyunca ani olarak genişleyen akış alanında hız azalarak basınç artmıştır. Bu artışın Bernoulli denkleminden beklendiği gibi hız yükünün basınç yüküne dönüşmesi şeklinde olması beklenir. Fakat bu artma işlemi gerçekte böyle gerçekleşmez (Çengel vd., 2008). Girdaplardan ve karışmadan kaynaklanan kinetik enerjinin bir kısmı 1sıya dönüşür. Sonuç olarak basınç enerjisinde çok ciddi bir artış meydana gelmez. Ele alınan nanoakışkan için hacim konsantrasyonunun artması ile basınç farkının arttığı görülmüştür. Çünkü basınç farkı konsantrasyonun bir fonksiyonudur. Konsantrasyon arttıkça basınç farkı da artar. Bunun nedeni ise viskozitenin konsantrasyonla artmasıdır. Partiküllerin yoğunluğunun artışı ile türbülans veya çalkantılar artarak moleküllerin hareketi zorlaşır, bu da basınç farkını artırır.

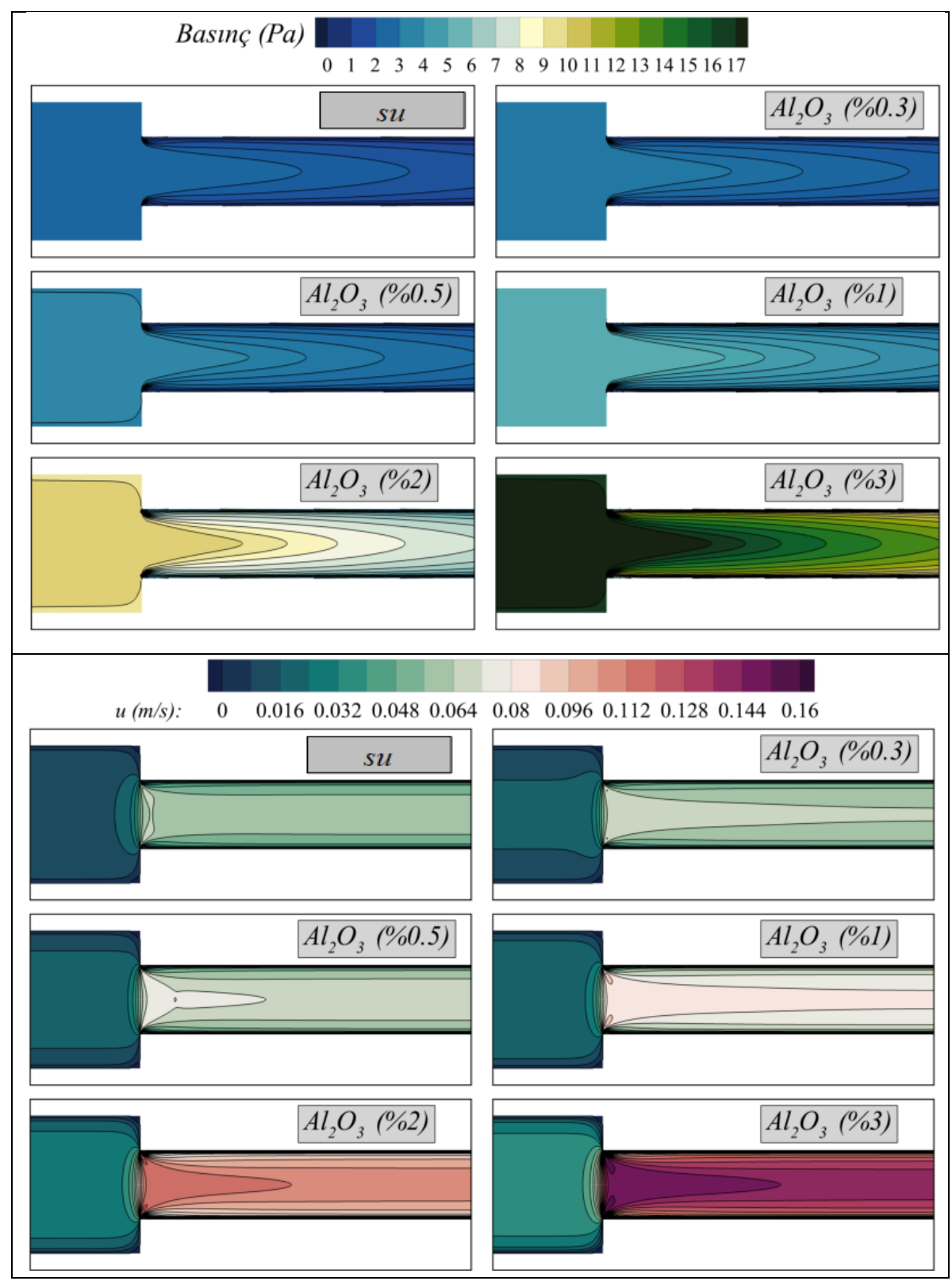

Şekil 2. Ani Daralma Bă̆lantı Parçası için basınçve hız dă̆ılımı $\left(\mathrm{Al}_{2} \mathrm{O}_{3}\right)$ 


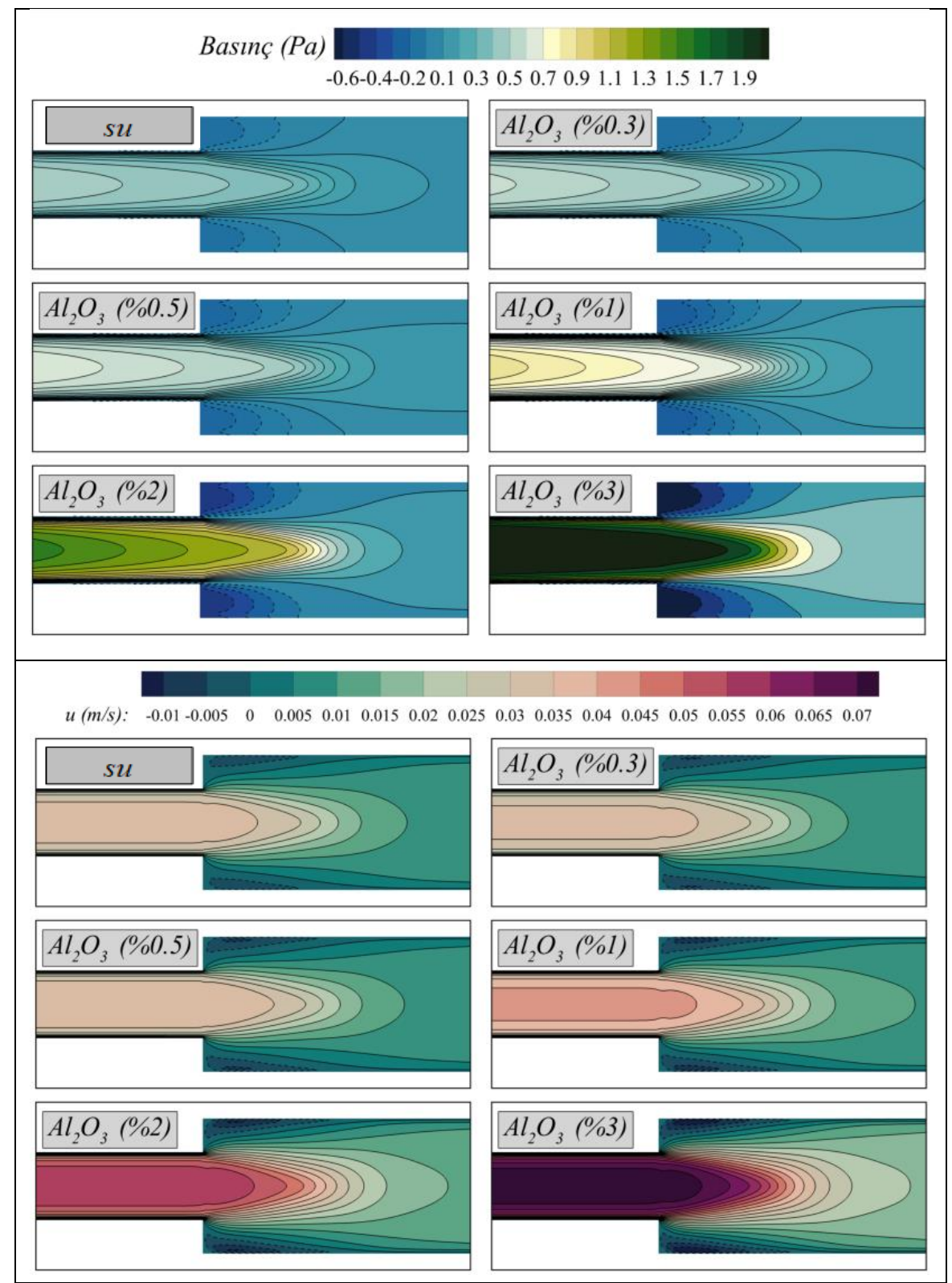

Şekil 3. Ani Genişleme Bağlantı Parçası için basınç ve hız dağılımı

\subsubsection{Su ve CuO Nanoakışkanı İçin Elde Edilen Sonuçlar}

Bağlantı parçaları ele alındığında, iki farklı türbülans modeli için hesaplanan yerel kayıp katsayı değerleri Tablo 5 ve Tablo 6 'da gösterilmiştir. Tablolar incelendiğinde, ani daralma ve ani genişleme bağlantı parçası için, nanoakışkanın hacim konsantrasyonu arttıkça, kayıp katsayısııın da arttı̆ğ görülmektedir.

Tablo 5. Bağlantı Parçalarının Kayıp Katsayıları, $\mathrm{K}_{\mathrm{k}}$, k - $\varepsilon$ modeli $(\mathrm{CuO})$

\begin{tabular}{ccc}
\hline \multirow{2}{*}{ Akışkanlar } & \multicolumn{2}{c}{ Kayı̀ Katsayıları, $\mathrm{K}_{\mathrm{k}}$} \\
\cline { 2 - 3 } & Ani daralma & Ani genişleme \\
\hline $\mathrm{Su}+\% 1 \mathrm{CuO}$ & 0.5321 & 0.632 \\
$\mathrm{Su}+\% 2 \mathrm{CuO}$ & 0.5482 & 0.666 \\
$\mathrm{Su}+\% 4 \mathrm{CuO}$ & 0.6010 & 0.730 \\
\hline
\end{tabular}

Tablo 6. Bağlantı Parçalarının Kayıp Katsayıları, Kk, k - $\omega$ Modeli $(\mathrm{CuO})$

\begin{tabular}{ccc}
\hline \multirow{2}{*}{ Akışkanlar } & \multicolumn{2}{c}{ Kayıp Katsayıları, $\mathrm{K}_{\mathrm{k}}$} \\
\cline { 2 - 3 } & Ani daralma & Ani genişleme \\
\hline $\mathrm{Su}+\% 1 \mathrm{CuO}$ & 0.4467 & 0.673 \\
$\mathrm{Su}+\% 2 \mathrm{CuO}$ & 0.4693 & 0.707 \\
$\mathrm{Su}+\% 4 \mathrm{CuO}$ & 0.5145 & 0.775 \\
\hline
\end{tabular}

Şekil 4’te ani daralma bağlantı parçasının basınç ve hız dağılımları görülmektedir. Ani girdap kopmalarından kaynaklı enerji kayıplarından dolayı, basınçta oldukça fazla bir artış meydana gelmiştir. Girişte basınç 2.6 Pa mertebesindeyken, çıkışta basınç $7 \mathrm{~Pa}$ mertebesine kadar ulaşmıştır. Ani daralma bağlantı parçasının basınç ve hızlarında diğer bağlantı parçalarına oranla daha fazla artış olduğu görülmüştür. $\mathrm{Bu}$ da pompalama gücünün en fazla bu bağlantı parçasında artacağı anlamına gelmektedir. Girişte hız $0.024 \mathrm{~m} / \mathrm{s}$ iken çıkışta $0.096 \mathrm{~m} / \mathrm{s}$ değerine kadar ulaşmıştır. Şekil 5'te görüldüğü gibi her bir bağlantı 
parçasının girişinden çıkışına doğru yöneldikçe basınç değerlerinde ani bir düşüş gözlenmiştir. Konsantrasyon bazında değerlendirildiğinde ise, her bir bağlantı parçası için giriş çapındaki basınç değerinin arttığı görülmektedir. Konsantrasyon arttıkça hız değerleri de artmıştır. her bir bağlantı parçası için düşünüldüğünde, giriş çapındaki hız değerinin çıkışa doğru gidildikçe aniden düştüğü, özellikle ani girdap kopmasının yaşandığı köşelerde dağılımın sıklaştığı görülmüştür.

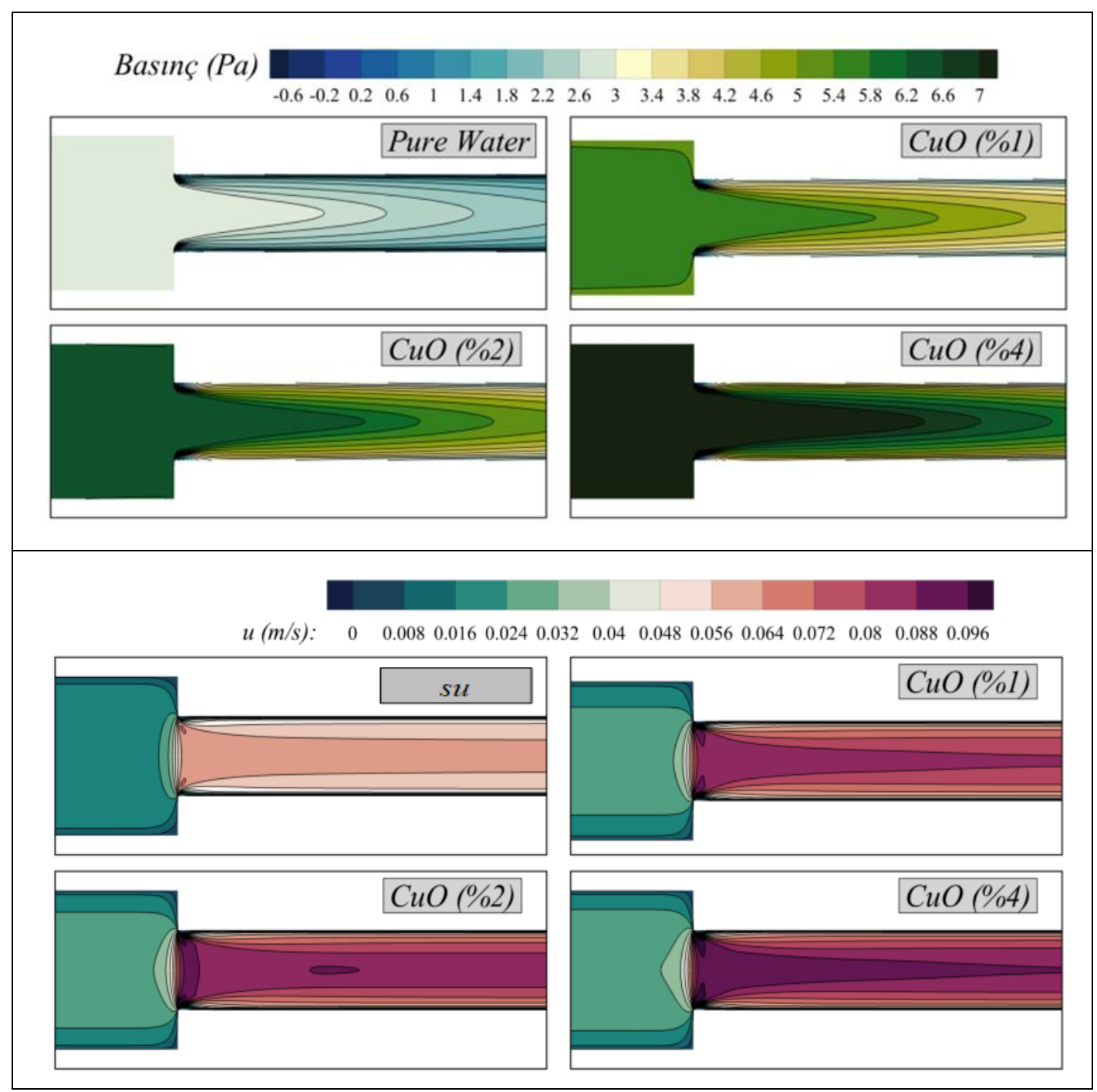

Şekil 4. Ani Daralma Bağlantı Parçası için basınç ve hız dăğlımları (CuO)

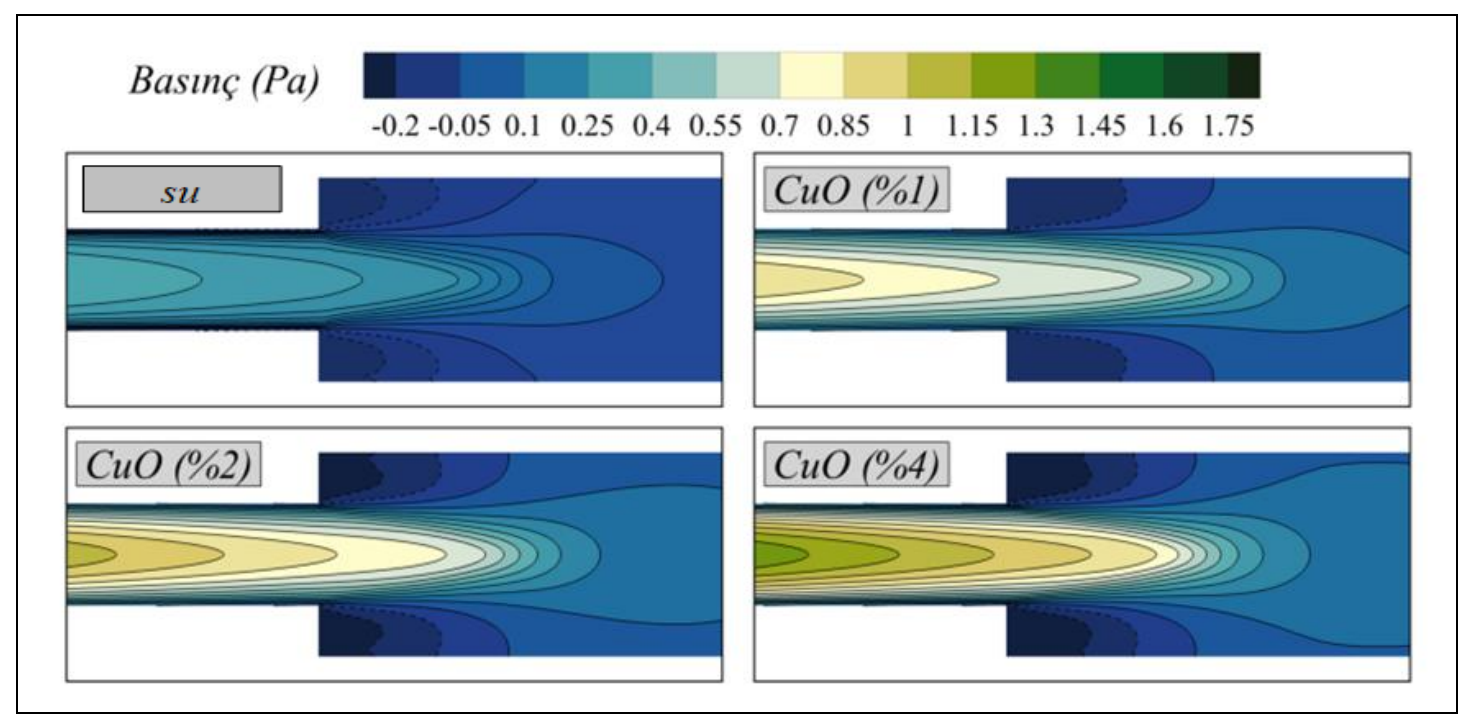




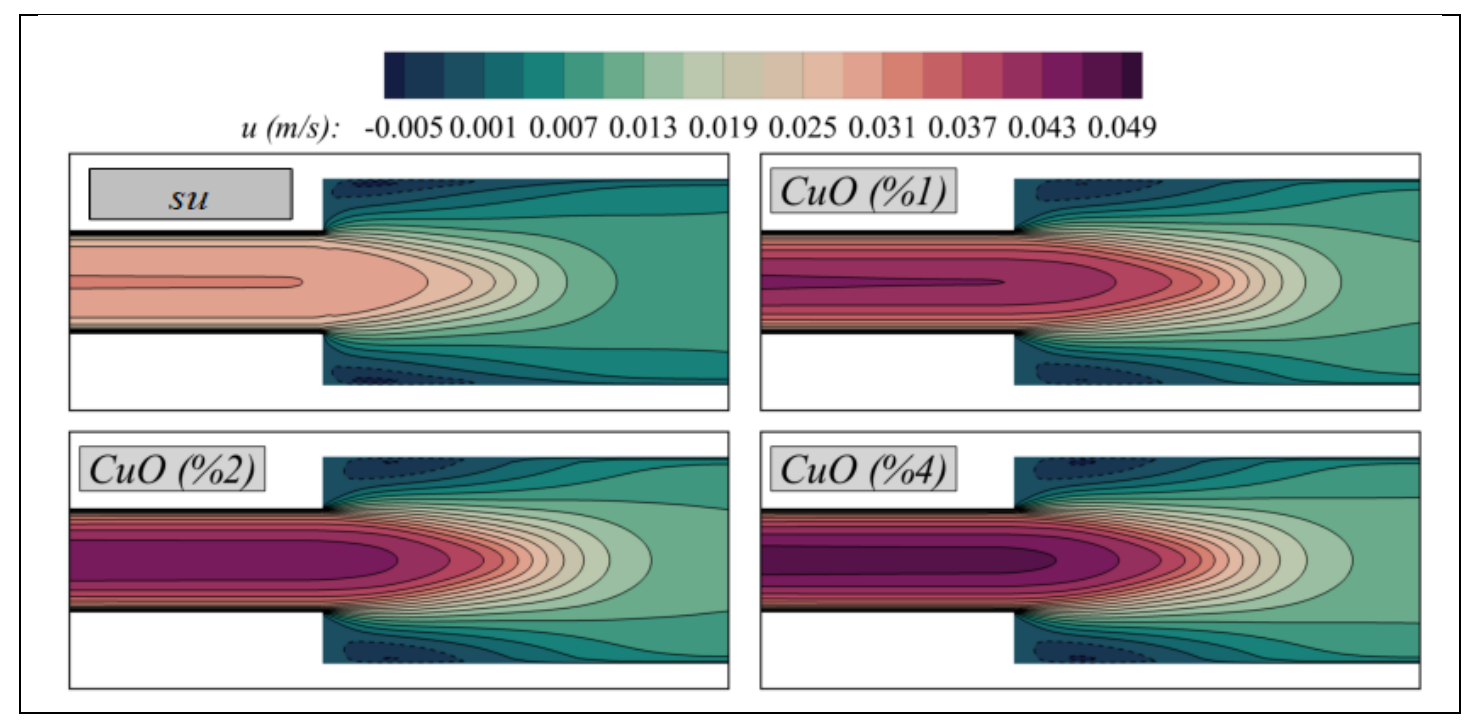

Şekil 5. Ani Genişleme Bağlantı Parçası için basınç ve hız dă̆llımları (CuO)

\subsubsection{Su ve $\mathrm{TiO}_{2}$ Nanoakışkanı İçin Elde Edilen \\ Sonuçlar}

Tablo 7 ve Tablo 8, Su + TiO2 nanoakışkanı için hesaplanan basınç kaybını ve yerel kayıp katsayılarını içermektedir. İki farklı türbülans modelinde de nanoakışkan hacim konsantrasyonu arttıkça bağlantı parçasındaki yerel kayıp katsayılarının arttığı görülmektedir.

Tablo 7. Bağlantı Parçalarının Kayıp Katsayıları, $K_{k}, k-\varepsilon$ modeli (TiO2)

\begin{tabular}{ccc}
\hline \multirow{2}{*}{ Akışkanlar } & \multicolumn{2}{c}{ Kayıp Katsayıları, $\mathrm{K}_{\mathrm{k}}$} \\
\cline { 2 - 3 } & Ani daralma & Ani genişleme \\
\hline $\mathrm{Su}+\% 0.05 \mathrm{TiO}_{2}$ & 0.6076 & 0.647 \\
$\mathrm{Su}+\% 0.1 \mathrm{TiO}_{2}$ & 0.6506 & 0.693 \\
$\mathrm{Su}+\% 0.3 \mathrm{TiO}_{2}$ & 0.8247 & 0.879 \\
$\mathrm{Su}+\% 0.5 \mathrm{TiO}_{2}$ & 1.369 & 3.282 \\
\hline
\end{tabular}

Tablo 8. Bağlantı Parçalarının Kayıp Katsayıları, $K_{k}, k$ - $\omega$ modeli (TiO2)

\begin{tabular}{ccc}
\hline \multirow{2}{*}{ Akışkanlar } & \multicolumn{2}{c}{ Kayıp Katsayıları, $\mathrm{K}_{\mathrm{k}}$} \\
\cline { 2 - 3 } & Ani daralma & Ani genişleme \\
\hline $\mathrm{Su}+\% 0.05 \mathrm{TiO}_{2}$ & 0.6804 & 0.690 \\
$\mathrm{Su}+\% 0.1 \mathrm{TiO}_{2}$ & 0.7292 & 0.739 \\
$\mathrm{Su}+\% 0.3 \mathrm{TiO}_{2}$ & 0.9244 & 0.957 \\
$\mathrm{Su}+\% 0.5 \mathrm{TiO}_{2}$ & 1.1191 & 1.135 \\
\hline
\end{tabular}

Şekil 6'da görüldüğü gibi ani girdap kopmalarının olduğu yerlerde basınç değerleri oldukça fazla artmaktadır. Düşük konsantrasyonlarda 1.6 Pa mertebesinde olan basınç değerinin konsantrasyon artışı ile $2.8 \mathrm{~Pa}$ mertebesine kadar çıktığı görülmektedir. Giriş bölgesinde hız değeri $0.022 \mathrm{~m} / \mathrm{s}$ değerinde iken, kesit daralmasıyla akışın aniden sıkışmasıyla hız değeri $0.054 \mathrm{~m} / \mathrm{s}$ değerine kadar çıkmıştır.

Şekil 7'de artan nanoakışkan konsantrasyonuna karşı basınç değerlerinin arttığı özellikle basınç dağılımlarının sıklaştığı görülmektedir. Ani genişleme bağlantı parçası için giriş çapında yüksek basınç değerleri görülürken, özellikle büyük enerji kayıplarının olduğu köşelerde ve alt kısımlarda basınç değerlerinin ani bir şekilde düştüğü gözlenmiştir. Hız dağılımları incelendiğinde yine konsantrasyon artışı ile hızın $\operatorname{arttığ~}$ gözlenmiştir.

$\mathrm{TiO}_{2}$ nanoakışkanın 4 farklı hacim konsantrasyonu da ele alındığında konsantrasyonun artışı ile basınç farkının da arttığı görülmektedir. Basınç farklarıyla hesaplanan yerel kayıp katsayı değerinin de arttığı görülmüştür.

\subsection{Farklı Nanoakışkanların Farklı Konsantrasyonlarında Pompa Gücü}

Eşitlik 12 kullanılarak farklı nanoakuşkanların artan hacimsel konsantrasyonlarında pompa güçleri hesaplanmıştır. Hesaplar sonucunda elde edilen grafikler Şekil 14,15 ve 16'da verilmiştir. 
European Journal of Science and Technology

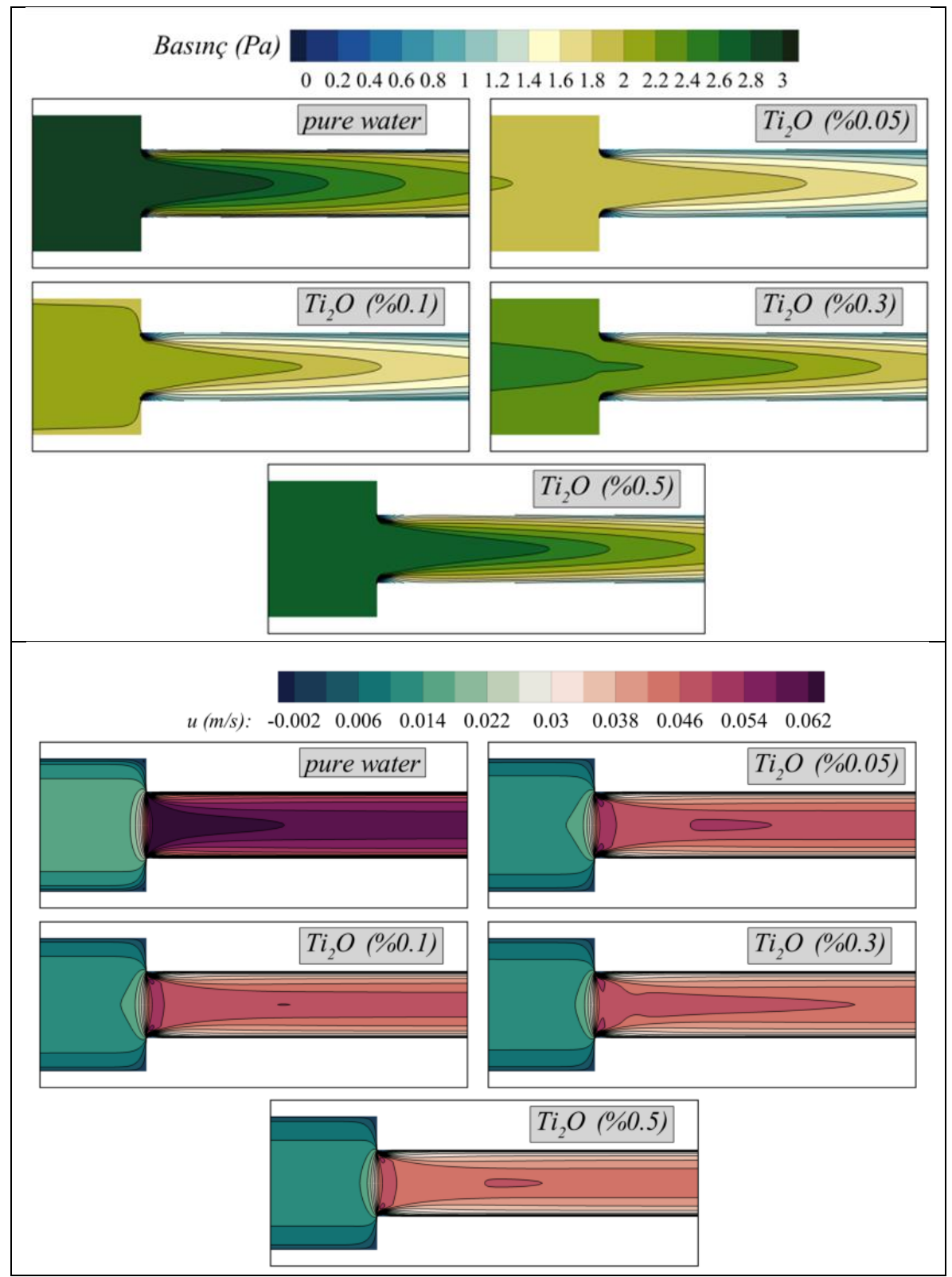

Şekil 6. Ani daralma bağlantı Parçası için basınç ve hız dağıllımları ( $\left.\mathrm{TiO}_{2}\right)$ 


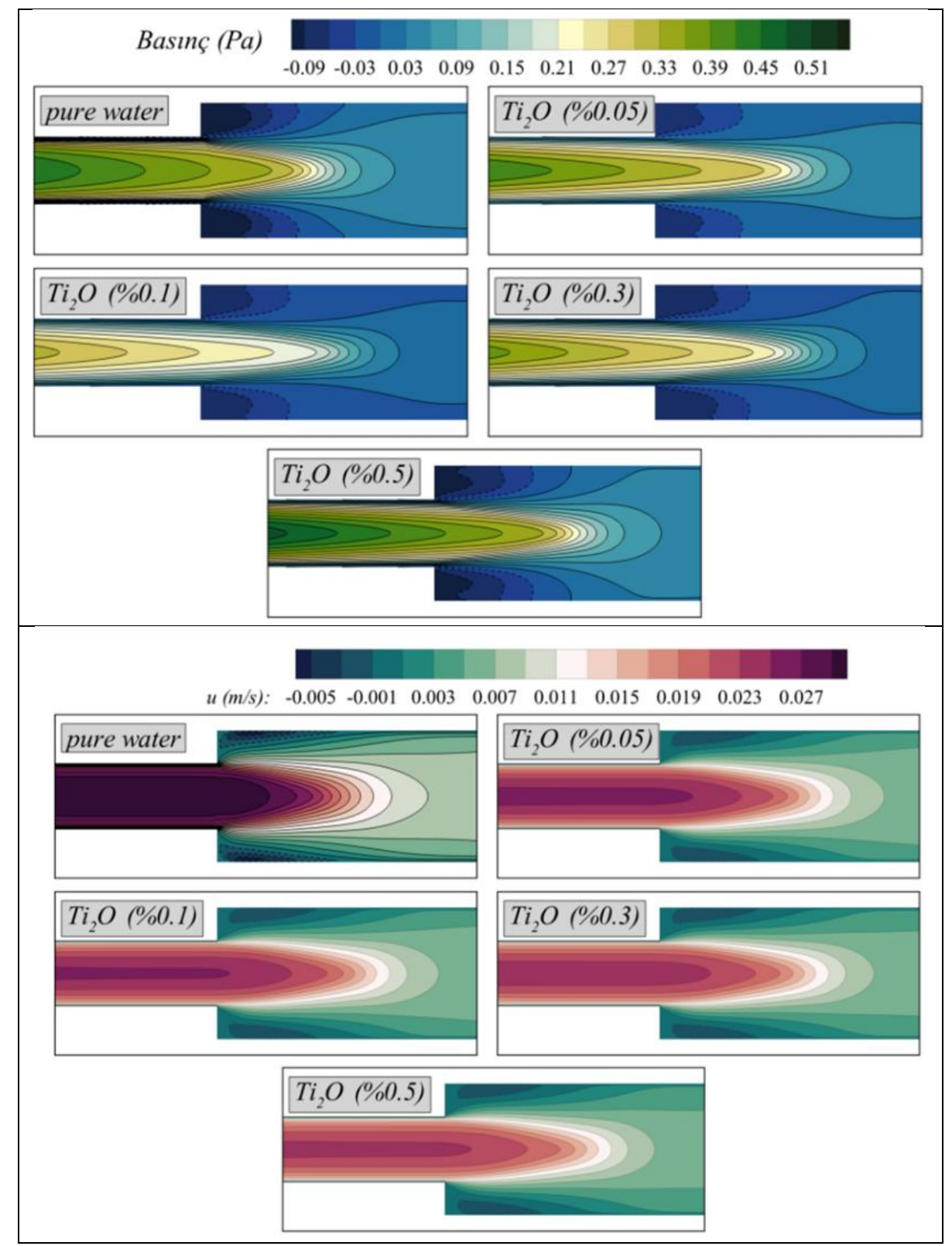

Şekil 7. Ani Genişleme Bağlantı Parçası için basınç ve hız dağıllımları ( $\left.\mathrm{TiO}_{2}\right)$

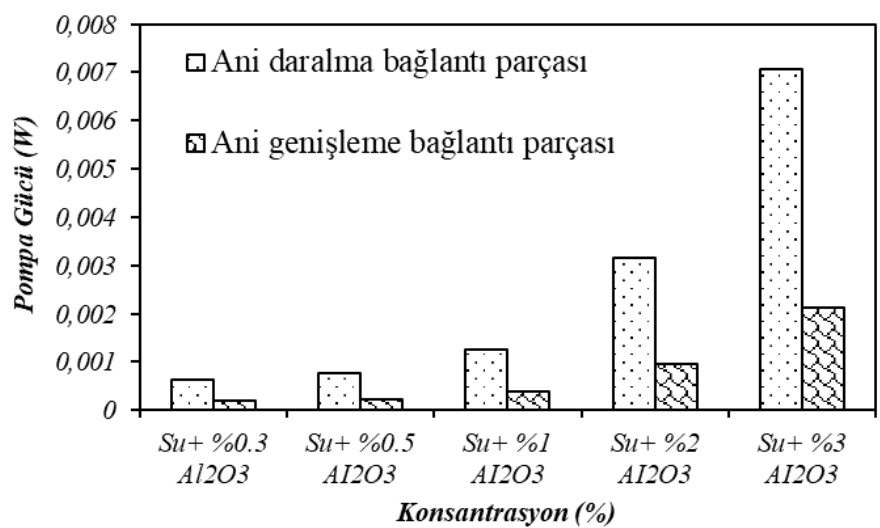

Şekil 8. $\mathrm{AI}_{2} \mathrm{O}_{3}$ nanoaklşkanının farkl konsantrasyonlarda pompa gücünün (W) artışı

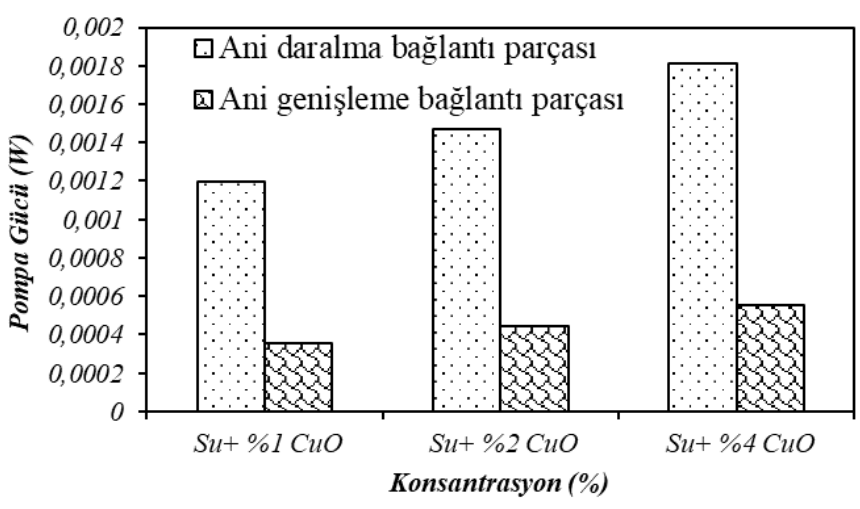

Şekil $9 \mathrm{CuO}$ nanoakışkanııın farklı konsantrasyonlarda pompa gücünün $(\mathrm{W})$ artış1 


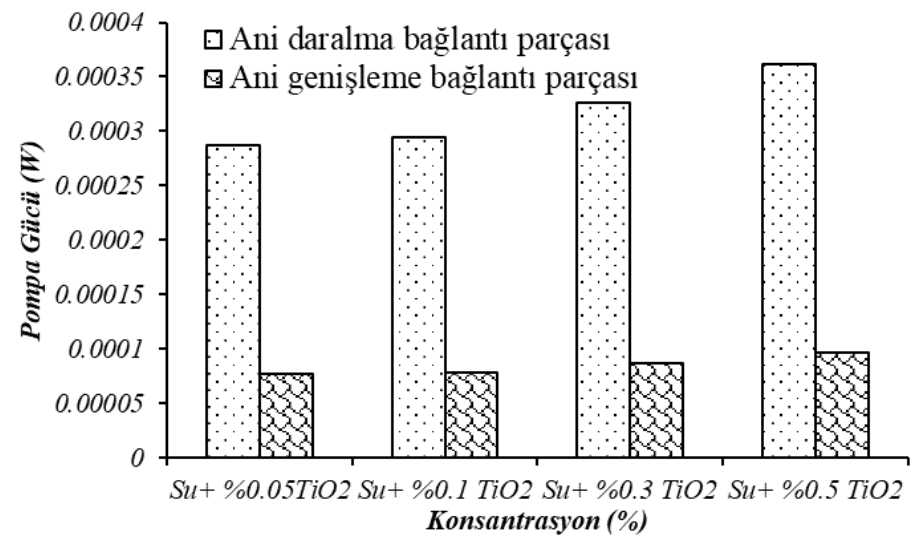

Şekil $10 \mathrm{TiO}_{2}$ nanoakışkanının farklı konsantrasyonlarda pompa gücünün (W) artışı

Grafikler incelendiğinde artan hacim konsantrasyonu ile pompa gücünün de arttığı görülmektedir. Bağlantı parçalarındaki yük kaybı geometriye bağlıdır. Ani daralma gibi keskin kenarlı bir giriş, bağlantı parçasına girerken akışkanın hız yükünün yarısının kaybolmasına neden olur. Boru içerisindeki akış, $90^{\circ}$ gibi keskin dönüşleri kolayca yapamaz. Ve bağlantı parçasının köşelerinde akış ayrılmaları oluşur, akış bağlantı parçasının orta noktasındaki daralmış kesite sıkıştırılır. Akışkan sıkıştığından hız artar ve oluşan türbülanstan girdaplarından dolayı bir kinetik enerji meydana gelir. Bu kinetik enerjideki sürtünme kayıplarının ısıya dönüşmesi ve bu ani girdap kopmalarından dolayı bağlantı parçalarının giriş ve çıkıştaki belirlenen noktalar arasında basınç fark1 çok fazla olmuş olur. Hacimsel konsantrasyon arttıkça nanoakışkan viskozitesi de artmaktadır. Pompa gücü için Reynolds sayısı, giriş hızı, hacimsel debi, basınç farkı gibi faktörler büyük önem taşımaktadır. Konsantrasyon arttıkça, gerekli duyulan pompa gücü de kayıpların atışı ile artmıştır.

\subsection{Farklı Ani Genişleme Bağlantı Parçasının Kayıp Katsayısı}

Ani genişleme bağlantı parçası ele alındığında yerel kayıp katsayısı giriş ve çıkış oranına göre değişmektedir (Çengel vd., 2008). Yerel kayıların incelenmesinde düz borudan olan sürekli kayıplara ek olarak dirsek bağlantı parçası, T bağlantı parçası, L bağlantı parçası ve redüksiyon gibi boru ekleme parçalarından olan basınç kayıpları da yerel kayıp olarak değerlendirilir. Boru ve boru parçalarının giriş ve çıkış çapları arasındaki oran da aslında yerel kayıpların belirlenmesinde çok önem arz etmektedir. Aşağıda dört farklı redüksiyon parçası (ani genişleme bağlantı parçası) fluent ANSYS programı kullanılarak çizilmiştir. $\mathrm{Bu}$ parçaların içerisinden su yerine piyasa en çok kullanılan $\mathrm{Al}_{2} \mathrm{O}_{3}$ nanoakışkanının \%3'lük konsantrasyonu kullanılmıştır. Burada kullanılan bağlantı parçalarının giriş çapları $20 \mathrm{~cm}$ çıkış çapları ise sırayla $30 \mathrm{~cm}, 40 \mathrm{~cm}, 50 \mathrm{~cm}$ ve $60 \mathrm{~cm}$ 'dir. Akış incelemesi Reynolds sayısı 5000 için yapılmış ve türbülans modeli olarak k$\varepsilon$ RNG modeli kullanılmıştır.

Redüksiyon parçası ele alındığında giriş ve çıkış çapları arasında artış oranı azaldıkça yerel kayıpların arttığı görülmüştür. Çıkış çapı arttıkça basınç değeri azaldığından yerel kayıplar da azalmıştır.
Çizelge 4. Ani Genişleme Bağlantı Parçası Reynolds Sayısı, $R e=5000 k-\varepsilon R N G$ Modeli

\begin{tabular}{|c|c|}
\hline $\begin{array}{c}\text { Bă̆lantı parçalarının giriş ve çıkış } \\
\text { çapları oranı }\left(\boldsymbol{d}^{2} / \boldsymbol{D}^{2}\right)\end{array}$ & $\left(\boldsymbol{K}_{\boldsymbol{k}}\right)$ \\
\hline 0.44 & 0.423 \\
\hline 0.25 & 0.651 \\
\hline 0.16 & 0.798 \\
\hline 0.11 & 0.915 \\
\hline
\end{tabular}

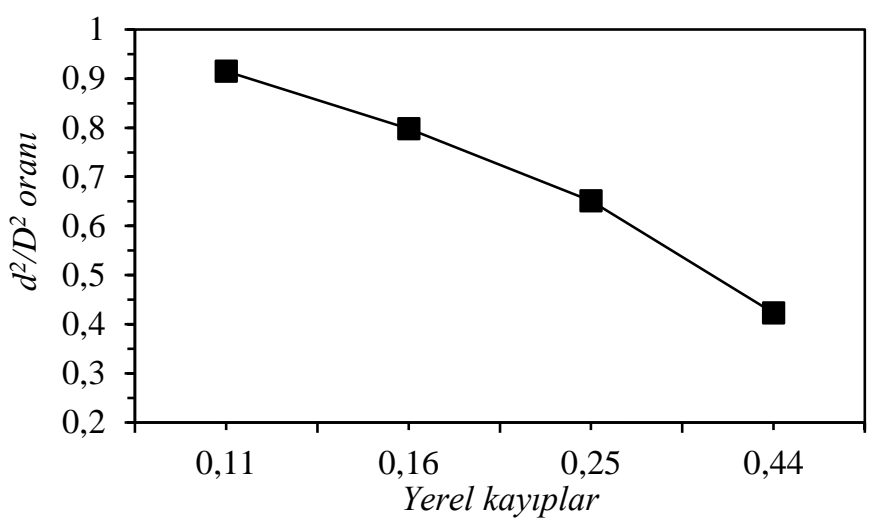

Şekil 11 Farklı ani genişleme bağlantı parçası yerel kayıp katsayıs grafiği

\section{Sonuç}

Yapılan bu çalışmada endüstrinin hemen hemen her alanında kullanılan bağlantı parçalarının içerisinden nanokakışkan geçirilip yerel kayıp katsayıları değerlendirilmiştir. Sayısal analiz sonucunda elde edilen veriler, teorik hesaplarla doğrulanmıştır. Ani daralma ve ani genişleme bağlantı parçalarının içerisinden alüminyum, bakır ve titanyum esaslı parçacıklar geçirilip basınç kayıpları sayısal olarak hesaplanmıştır. Konsantrasyon artışı ile yerel kayıp katsayısının ve basınç düşüsünün arttığı görülmüştür. Yerel kayıp katsayısının artışının $\mathrm{Al}_{2} \mathrm{O}_{3}, \quad \mathrm{Ti}_{2} \mathrm{O}, \mathrm{CuO}$ nanoakışkanlarının termofiziksel özellikleri ve akışın türbülanslı olmasıyla ilişkili olabileceği görülmüştür. $\mathrm{Al}_{2} \mathrm{O}_{3}(\% 0.3, \% 0.5$, $\% 1, \% 2, \% 3), \mathrm{Ti}_{2} \mathrm{O}(\% 0.05, \% 0.1, \% 0.3, \% 0.5)$ ve $\mathrm{CuO}(\% 1, \% 2$, \%4) nanoakışkanlarında incelenen birçok farklı modelde hacim konsantrasyonlarındaki artışa bağlı olarak dinamik viskozitenin artışı ile basınç farkının da arttığı görülmüştür. Sayısal çözümlemelerde k- $\varepsilon$, k- $\omega$ Standard türbülans modeli olmak üzere iki farklı model kullanılmıştır. Her iki bağlantı parçası için en uygun modelin $\mathrm{k}-\varepsilon$ modelinin uygun sonuçları verdiği doğrulanmıştır.

\section{5. Özel Not}

Sunulan bu çalışma Mürüvvet Avcı'nın Dr. Nehir TOKGÖZ danışmalığında yürüttüğü yüksek lisans tezinin bir parçasıdır.

\section{Kaynakça}

Artuç, M. (2007). Nanoakışkanların ısıl iletkenliklerinin ölçülmesi. Yüksek Lisans Tezi.

Awang, M. T. (2010). Development of Regression Equation for Heat Capacity and Density of Nanofluids Properties. Universiti Malaysia Pahang. 
Bedir, Ö. (2013). Sabit Isı Akılı Yatay Bir Boruda Zorlanmış Türbülanslı Akışta Nanoakışkanların Sayısal Incelenmesi. Doktora Tezi.

Bergles, A. (1983). Augmentation of Heat Transfer. Heat Exchanger Design Handbook. Hemisphere Publishing, New York, secs, 2(11), 489-501.

Bianco, V., Chiacchio, F., Manca, O., \& Nardini, S. (2009). Numerical investigation of nanofluids forced convection in circular tubes. Applied Thermal Engineering, 29(17-18), 3632-3642.

Choi, S. U., \& Eastman, J. A. (1995). Enhancing thermal conductivity of fluids with nanoparticles. Retrieved from

Çengel, Y. A., Cimbala, J. M., \& Engin, T. (2008). Akışkanlar mekaniği: temelleri ve uygulamalart: Güven Kitabevi.

Duangthongsuk, W., Yiamsawasd, T., Selim Dalkilic, A., \& Wongwises, S. (2013). Pool-boiling heat transfer characteristics of Al2O3-water nanofluids on a horizontal cylindrical heating surface. Current Nanoscience, 9(1), 5660.

Ganvir, R., Walke, P., \& Kriplani, V. (2017). Heat transfer characteristics in nanofluid-a review. Renewable and Sustainable Energy Reviews, 75, 451-460.

Gavtash, B., Hussain, K., Layeghi, M., \& Lafmejani, S. S. (2012). Numerical simulation of the effects of nanofluid on a heat pipe thermal performance. International Journal of Mechanical and Mechatronics Engineering, 6(8), 1462-1468.

Hassanzadeh, R., \& Tokgoz, N. (2017). Thermal-hydraulic characteristics of nanofluid flow in corrugated ducts. Journal of Engineering Thermophysics, 26(4), 498-513.

Hosseini, S. S., Shahrjerdi, A., \& Vazifeshenas, Y. (2011). A review of relations for physical properties of nanofluids. Australian Journal of Basic and Applied Sciences, 5(10), 417435.

Kakaç, S., \& Pramuanjaroenkij, A. (2016). Analysis of convective heat transfer enhancement by nanofluids: single-phase and two-phase treatments. Journal of Engineering Physics and Thermophysics, 89(3), 758-793.

Kulkarni, D. P., Namburu, P. K., \& Das, D. K. (2016). Comparison of heat transfer and fluid dynamic performance of nanofluids. Une, 13, 15.

Gedik, E., Kayfeci, M., Keçebaş, A., Kurt, H. (2017). Dairsel bir boruda $\mathrm{Al}_{2} \mathrm{O}_{3} / \mathrm{su}$ ve Tio2/su nanoakışkanların laminer zorlanmış 1sı taşınımı, TTMD Dergisi, 48-53,

Murshed, S., Leong, K., \& Yang, C. (2008). Thermophysical and electrokinetic properties of nanofluids-a critical review. Applied Thermal Engineering, 28(17-18), 2109-2125.

Özbey, M. (2016). Experimental study on pressure drop of aluminum-oxide/water nanofluids. Journal of Thermophysics and Heat Transfer, 30(2), 342-349.

Şahin, B., ÇomaklI, K., Çomaklı, Ö., \& Yılmaz, M. (2006). Nanoakışkanlar ile 1sı transferinin iyileştirilmesi. Mühendis ve Makina, 47(559), 29-34.

Timofeeva, E. V., Yu, W., France, D. M., Singh, D., \& Routbort, J. L. (2011). Nanofluids for heat transfer: an engineering approach. Nanoscale research letters, 6(1), 1-7.

Tokgöz, N., Alıç, E., Kaşka, Ö., \& Aksot, M. (2018). The numerical study of heat transfer enhancement using $\mathrm{Al}_{2} \mathrm{O}_{3}$ water nanofluid in corrugated duct application.

Vajjha, R., Das, D., \& Mahagaonkar, B. (2009). Density measurement of different nanofluids and their comparison with theory. Petroleum Science and Technology, 27(6), 612624.
Wilcox, D. C. (1988). Reassessment of the scale-determining equation for advanced turbulence models. AIAA journal, 26(11), 1299-1310. 